\title{
Central Line Complication
}

National Cancer Institute

\section{Source}

National Cancer Institute. Central Line Complication. NCI Thesaurus. Code C121589.

A problem with a central venous access catheter or site of insertion. 